\title{
Environmental Governance in India: A Good Governance Perspective
}

\author{
${ }^{*}$ Manish Kumar
}

Associate Professor in Political Science, Rayat College of Law, Shaheed Bhagat Singh Nagar, Punjab-144533

\begin{abstract}
At the outset good governance aims at providing responsive, transparent, clean and people-friendly administration. Implicitly accountability, both political and administrative, is one of essential elements of multi-faceted concept of good governance. This paper attempts to approach and view realization of good governance in environmental governance in India.
\end{abstract}

Keywords: good governance, environmental governance, environmental degradation

\section{Article Publication}

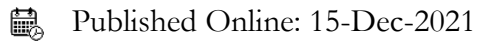

*Author's Correspondence

8 Manish Kumar

9 Associate Professor in Political Science, Rayat College of Law, Shaheed Bhagat Singh Nagar, Punjab-144533

$\bowtie$ manish.jaryal@gmail.com

C 2021The Authors. Published by RESEARCH REVIEW International Journal of Multidisciplinary. This is an open access article under the CC BY-

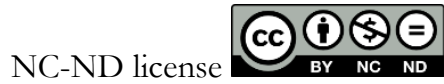

(https://creativecommons.org/licenses/ by-nc-nd/4.0/)

\section{Introduction}

It has been established by several research studies that the governance is a critical factor for protection and conservation of environment (Ostrom, 1999; Lockwood et al, 2010; Armitage et al, 2012). Contextually governance refer to an effective utilization of resources for development, thus it transcends the ambit of government to embrace informal and non-government institutions.

Environmental Governance, in particular, pertains to the practices aim at managing natural resources. Any discourse on environmental governance essentially involves efficacy of these practices in terms of sustainability Bennette and Satterfield, 2018). United Nations Environment Programme, more particularly, points up the rules, practices and institutions as environmental governance which fashion the relation between human and environment. Resultantly, environmental governance while shaping the human actions vis-à-vis environment, becomes critical in sustainable utilization of environment resources (Armitage et al, 2012; Termeer and Liehout, 2010).

\section{Environmental Governance in India}

As far as the pre-independence period is concerned, India has moderate legacy of environment protection laws. Even after the independence in 1947, the steps towards giving a concrete shape to environmental governance were taken after the year of 1972. The first legislation in this direction, passed in 1974, was Water (Prevention and Control of Pollution) Act, 1974. An amendment was made in 1976 in the Constitution to incorporate Art 48A in part IV i.e. the Directive Principle of State Policy to mandate the state to act upon "protection and improvement of environment, conservation of forests and safety of wildlife". 
Also, every citizen in India was exhorted to preserve green cover, water bodies, forest life and the atmosphere at large, through a fundamental duty under Art 51A incorporated during the same time. The government of India has passed a slew of legislations with an objective to protect environment since then, which include the Forest (Conservation) Act 1980, the Air (Prevention and Control of Pollution) Act 1981. The Government of India was latter triggered by the Bhopal gas tragedy to bring in the Environment (Protection) Act 1986. Earlier in 1985 the union Ministry of Environment and Forest was created.

\section{Environmental Issues in India}

Despite devising the structure for environmental governance and enacting various legislative measures, the environmental concerns do not find the required weight vis-à-vis development in the process of policy making. The efforts of the governments both at the center and the economic growth hungry states to devise a link between growth and environmental sustainability are far from encouraging. There are still miles to go before we attain this sustainability in view of the dismal state of environment in India. Poor quality air, contamination and depletion of water, degradation of soil, loss of bio-resources and wildlife, loss of ability of ecosystem to replenish itself and unplanned solid waste disposal etc. are foremost problems which our environment is facing.

Poor quality air and water, for instance, is affecting the health of people in India; the negative impact on the health of children is even more severe. The $W H O$ in its reports has revealed that over ninety per cent of the people across the world are braving poor air quality. In 2015, The Lancet Commission on Pollution and Health blamed air pollution for nine million premature deaths across the globe. The number of these deaths was alarmingly high in India (Mazizini, 2017). According to one estimate, the presence of excessive pollution in the environment has reduced the average life of Indians by 3.2 years (The Economics Times, 2015). While highlighting its concern over air pollution related disease the WHO point up that seventy-lakh people prematurely die annually because of air pollution-induced disease. This situation is more grievous in the developing countries like India (Bhargav and Reddy, 2018). It also says that thirty-three per cent of the deaths from ailments such as brain-stroke, lung diseases and cardiovascular disorder are due to pollution in the air (BBC, 2019).

Sadly, India remained a top polluter on the global list with majority of the topmost cities showing the highest levels of very fine particles in the air that can become the cause severe cardiovascular disorders and respiratory diseases (Bhargav and Reddy, 2018). It is a matter of concern that no region in India is untouched by the problem of air pollution as these cities, with high level of PM2.5, locate across the states. Unsurprisingly, these and other tier 2 \& 3 cities lack adequate monitoring capacity. We still do not find any encouraging sign for much required transition from solid fuel to clean energy for cooking. Around two third of the household in India (percentage is more in rural areas) continue to use traditional sources of fuels for domestic use. The smoke from households is adding 13-35 per cent to the ambient PM2.5 load in majority of the big cities and this percentage is even higher in the villages (Bhargav and Reddy, 2018).

More recently, people in Delhi are fighting with pollutions that had reached 'severe' and 'emergency' level. The $C M$ of national capital called this region as a "gas chamber". As per some air quality index air pollution in in the NCR has crossed the level deemed safe by the World Health Organization by almost 50 per cent (Irfan, 2019). The people in Delhi are inhaling polluted air particles equivalent to consuming 50 cigarettes in one day (The Economic Times, 2019). The condition is equally alarming for many of the other areas; emission in about 11 per cent of the cities in northern part of India is ten times poorer than that of international standards. In terms of clean environment, the global ranking of India in not encouraging as the Global Environmental Quality Performance Index positioned it at the 177th place amongst 180 nations (Irfan, 2019).

Another major issue is polluting rivers in India. In its various judgements, the apex judiciary in India has encompassed the right to a clean and healthy environment within the ambit of fundamental rights. While hearing the plea of Delhi Jal Board the Supreme Court noted "The right to clean environment and further, pollution free water has been protected under the broad rubric of the right to life guaranteed under Art. 21." Despite the 
stringent preventive regulations devised by the government, the pollution causing material continues to be discharged in rivers unabatedly.

The religious freedom protected as a fundamental right in India is essentially accompanied by some reasonable restrictions to protect the common interest. Major religious festivals in India, over the period of time, have been playing havoc on the environment, particularly rivers in India. The releasing of painted idols in the water bodies causes mixing of hazardous heavy metals into the water. Sadly, we cannot find much evidences of the government's initiative to persuade the people to adopt environmentally sensitive religious practices. Whichever measures have been taken; these have been initiated by the judiciary (Rosencranz and Nath, 2017).

\section{Lack of Effective Governance}

The growth hungry developing countries throughout the globe, are passing through a phase of transition whereby shifting their economies from agrarian to industry-based and societies are getting more urbanized. One of the severe consequences of this shift is air pollution caused by both natural and human factors. The environmental governance in India has been unable to check the sources of pollution in this context as the stakeholders such as farmers, builders, construction companies, energy producers hold a strong political clout in the electoral arena.

Recently, India has become $65^{\text {th }}$ country to formally join Climate and Clean Air Coalition on World Environment Day celebrations and declared its commitment through National Clean Air Programme to ensure clean environment. Globally, India has taken a slew of measures in the recent past for development of technology and infrastructure with an objective to ensure clean environment. The UNEP has credited India to be a facilitator for a global alliance to harness solar energy, which will go a long way to mitigate the challenges of climate change. More recently, India has notified a raised standard of vehicular emission i.e. BS6 at par with Euro6. Further, the country has adopted an ambitious target to completely replace the sale of new vehicle with electric vehicles (UNEP, 2019).

The government seems to be progressive in terms of policies on paper. However, the zeal does not match when it comes to implementation. An evident lack of political will can be observed to check even the most visible detrimental impact on the environment. Time and again the government, at the level of both the center and states, found wanting in terms of response to the crisis of air pollution (Petersen, 2019). Another uninspiring approach of union as well as state government is evident in non-implementation of report of The Western Ghats Ecology Expert Panel, appointed by the Ministry of Environment and Forests in 2010. The report, popularly known as Gadgil Report, warned in August 2011 of imminent natural disaster in Western Ghats region, unless urgent steps were taken to protect eco-sensitive zones. The state of Kerala had witnessed this anticipated natural disaster in the devastating floods. The effectiveness of environment governance in India is also found lacking in almost all other aspects of environmental protection, conservation and sustainability. Ominously, it has not been successful in inspiring the people to imbibe and observe the values of environment conservation and sustainability.

\section{The Way Out}

Any further degradation of environment can cause a series of devastation year after year (Gadgil, 2019). The existing policy measures are not sufficiently pragmatic to address the problem (Gupta, 2019). The possible solution lies in effective environmental governance and motivated participation of people for protection of environment.

An operational environmental governance across the strata is vital to devise resolutions to this problem. To attain long term vision and goals with regard to protection and sustenance of environment, an operational environmental governance must be backed by an unwavering commitment on the part of political leadership. Good environmental governance, as UNEP emphasizes "takes into account the role of all actors that impact the environment, from governments to NGOs, the private sector and civil society, cooperation is critical to achieving effective environmental governance." It has four general aims or objectives- "to be effective, to be equitable, to be responsive and to be robust." These must be adhered to in a coordinated manner throughout the institutional, structural and procedural aspects of environmental governance. 
In this light, it's high time that environmental governance adopted ideals of good governance, particularly in terms of effectiveness and accountability. We must strengthen the democratic process and establish the rule of law with reference to environmental governance. It is really apt to quote the young Swedish activist Greta Thunberg here, "We cannot solve a crisis without treating it as a crisis, and if solutions within the system are so impossible to find, we should change the system itself." We must not forget, as emphasized by the UNEP "further degradation of environment will threaten individual livelihoods as well as local, national and international economies." More seriously, it will deprive our coming generations of their right to a meaningful life.

\section{References}

Armitage, D., de Loe R., Plummer R. et al. Environmental governance and its implications for conservation practice. Conservation Letters, 2012; 5: 245-255.

BBC Report. Available at https://www.bbc.com/news/world-asia-india-50280390; November 4, 2019

Bennett, Nathan J. and Satterfield T. Environmental governance: A practical guide design, evaluation, and analysis. Available at https://doi.org/10.1111/conl.12600; 2018

Bhargav K. and Reddy S K. Public health in times of environmental pollution. Business Line, 2018, May 11.

Gadgil, M. In an Interview by Cithara Paul. The Week, 2019, December 15.

Gupta, J. Spotlight on synergy between Health and Environment. Available at https://www.thehinducentre.com/thearena/article26495528.ece; 2019, March 13.

Hannah, A P. Delhi residents engulfed in pollution blame authorities for inaction. The Guardian. Available at https://www.theguardian.com/world/2019/nov/04/delhi-residents-engulfed-in-pollution-blame-authorities-forinaction; 2019, November 4.

Irfan, U. The law that's helping feul Delhi's deadly air pollution" Available at https://www.vox.com/science-andhealth/2019/11/8/20948348/delhi-india-air-pollution-quality-cause; 2019, December 16.

Lockwood, M, J. Davidson, A. Curtis et al. Governance principle for natural resource management. Society and Natural Resources, 2010; 23: 986-1001.

Mazzini, A P. India tops global pollution deaths of 9 million a year: study. Reuters, 2017, October 20.

Ostrom, E. Copping with the tragedies of the commons. Annual Review of Political Science, 1999; 2: 493-535.

Rosencranz, A and Nath R. The Hindu God is no longer green. Asia and the Pacific Policy Society, available at https://www.policyforum.net/hindu-god-no-longer-green/; 2017, December 5.

The Economic Times, 2015, February 23. Available at https://m.economictimes.com/news/politics-and-nation/airpollution-cutting-660-million-lives-short-by-3-years-report/articleshow/46337426.cms

The Economic Times, 2019, October 28. Available at https://economictimes.indiatimes.com/news/politics-andnation/delhi-air-right-now-is-like-smoking-50-cigarettes-a-day/killer-air/slideshow/71789493.cms

UNEP, 2019, July 5. Available at https://www.unenvironment.org/news-and-stories/press-release/india-joins-climateand-clean-air-coalition 